\section{Géneros}

Multidisciplinary Journal of Gender: Studies

\section{Hipatia Press \\ www.hipatiapress.com}

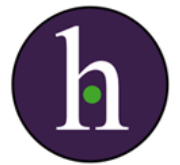

Instructions for authors, subscriptions and further details:

$\underline{\text { http://generos.hipatiapress.com }}$

\title{
What Is the Problem? Representations of Men's Violence Against Women in a Swedish Context
}

Helena Hoppstadius ${ }^{1}$

1) Department of Social Work, Mid Sweden University, Sweden

Date of publication: October $25^{\text {th }}, 2018$

Edition period: October - February 2019

To cite this article: Hoppstadius, H. (2018). What is the problem? Representations of men's violence against women in a Swedish context. Multidisciplinary Journal of Gender Studies, 7(3), 1684-1708. doi: 10.17583/generos.2018.3737

To link this article: http://dx.doi.org/10.17583/generos.2018.3737

PLEASE SCROLL DOWN FOR ARTICLE

The terms and conditions of use are related to the Open Journal System and to Creative Commons Attribution License (CC-BY). 


\title{
What Is the Problem? Representations of Men's Violence Against Women in a
}

\section{Swedish Context}

\author{
Helena Hoppstadius \\ Mid Sweden University
}

\section{Abstract}

Abuse and violence against women is not only a serious violation of human rights, but is also, according to the Swedish government, the most acute and greatest obstacle to a gender-equal society. The aim of the current study was to investigate discourses that govern social work practice in Sweden analysed discourses of violence against women in five Swedish public working guidelines using Carol Bacchi's social constructivist analytical approach What's the Problem Represented to Be? Our findings show that violence is framed in the guidelines within a heterosexual context and is represented as an individual problem of women within close relations and families. This framing also promotes a division between violence against Swedish-born women and violence against foreign-born women. The analysis also shows that equality seems to be more about the inclusion of men rather than looking after women's situations. How violence against women is understood will affect how violence can be predicted, prevented, and treated, and thus there is a risk that these representations might affect women subjected to violence differently depending on how social workers interpret and apply these guidelines. Findings also suggest that these representations maintain gender hierarchies and other structural and societal inequalities and ignore violence against women as a major global social problem.

Keywords: men's violence against women, violence in close relationships, honourrelated violence, social work, social policy 


\title{
¿Cuál Es el Problema? Representaciones de la Violencia de los Hombres Contra las Mujeres en el Contexto Sueco
}

\author{
Helena Hoppstadius \\ Mid Sweden University
}

\section{Abstract}

Los abusos y la violencia contra las mujeres constituyen una grave violación de los derechos humanos, y de acuerdo al Gobierno sueco, es el obstáculo principal en una sociedad de igualdad de género. El objetivo de este estudio fue investigar los discursos que rigen la práctica del trabajo social en Suecia, analizamos discursos de violencia contra mujeres en cinco directrices de servicio público en Suecia usando el enfoque analítico constructivista social de Bacchi (1999). Los resultados muestran que la violencia se enmarca en un contexto heterosexual e individual de mujeres en relaciones cercanas y familiares. Se verifica una diferencia entre violencia contra mujeres nacidas en Suecia y las nacidas en el extranjero. Asimismo se muestra que el foco de esa similitud es la mayor atención que se brinda a la inclusión de los hombres, sobre la situación de las mujeres. La definición de violencia contra las mujeres afecta la forma de predecir, prevenir y tratar esta, así como la interpretación e implementación de las directrices. Nuestros resultados verifican que estas representaciones reproducen inequidades estructurales y jerarquías de género ignorando la violencia contra las mujeres como un importante problema social global.

Keywords: violencia de hombres contra mujeres; violencia en relaciones cercanas, violencia relacionada con el honor; trabajo social; política social 


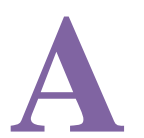

buse and violence against women is not only a serious violation of human rights (e.g. Garcia-Moreno, 2006), but is also, according to the Swedish government, the most acute and greatest obstacle to a gender-equal society (Regeringen, 2018). The work to combat men's violence against women has been on the political agenda in recent decades, and academics, activists, social workers, and social reformers have issued a call to action. The visibility of the problem and its magnitude have resulted in a great deal of commitment, and various lobbying organisations have succeeded in challenging attitudes sanctioning violence against women (Eduards 2002; Heise et al. 2002; Mattsson 2011). Swedish legislation has been tightened to protect women, and there have been several changes in policy regarding violence against women since 1965 when Sweden was the first country in the world to introduce a law against marital rape.

Despite changes in legislation and new approaches to the problem, men's violence against women is still a frequent and serious problem. Estimates are that every third woman in the world has been subjected to violence at some point in her life, and women are more frequently subjected to violence by a person close to them compared to men (Johnsson-Latham, 2005; World Health Organization, 2014; Hvitfeldt, Westerberg \& Irelander Strid, 2016). The superior position of men in society furthermore contributes to the fact that women's life situation is affected to a greater extent than men in similar situations (Holmberg, Stjernqvist, \& Sörensen, 2005).

Over the past decade, the Swedish Government has increased its efforts to combat violence and to increase the awareness of violence against women. This ambition is evident by various policies such as the Swedish government's communication "Power, goals and agency - a feminist policy" (Skr. 2016/17:10) and the government's “Action Plan for combating men's violence against women, violence and oppression in the name of honour, and violence in same-sex relationships" (Skr 2007/08:39).

How men's violence against women is framed in policies has practical significance on several levels. This is because in addition to clarifying society's position, the frameworks of such policies also highlight how to pay attention to and address a particular problem. A policy operates on both a practical because it is centred on a real "problem" and on a symbolic level because it represents or attempts to influence society's values and beliefs 


\section{Helena Hoppstadius - Men's Violence Against Women}

(Krizsan \& Popa, 2010; Murray \& Powell, 2009). Such policies in turn have an impact on professionals', for example, social workers', understandings, reflections, and practices (e.g. Burnett, Ford-Gilboe, Berman, Wathen, \& Ward-Griffin, 2016; Ljungwald, 2011). Therefore, because policies have a normative role, it is important to consider how they represent a certain problem and what the consequences of such representations might be.

The purpose of this study was to examine discourses about violence against women that govern social work practice in Sweden using Carol Bacchi's social constructivist analytical approach What's the Problem Represented to $B e$ ? (WPR). Discourses of violence against women in five Swedish public working guidelines that were derived from the "Action Plan for combating men's violence against women, violence and oppression in the name of honour, and violence in same-sex relationships" (Skr 2007/08:39). This work focused on three central research questions. (1) How do the working guidelines term men's violence against women? (2) Which theories are used to explain violence against women? (3) How is violence against women defined?

\section{Policy representations of violence against women}

The problem of violence in general is situated in contexts where different discourses express society's view of the problem in the shape of legal aspects, social norms, and media attention (Ljungwald, 2011; Lorentzen, 2008; Wendt, 2002). These discourses change over time and affect those considered to be victims of violence and perpetrators, how to consider causes of violence, what acts are regarded as violent acts, and so on.

In addition, the terms used to name violence against women, such as family violence and domestic violence, can be understood in different ways. On the one hand, the policies define the terms that are used, and thus they can include different persons in different policy contexts. For example, in an Australian context the terms family violence and domestic violence include family members, former partners, people sharing the household, and/or other related persons regardless of gender depending on which policy is being considered (Murray \& Powell, 2009). In Canadian policy use, the term family violence pays particularly attention to children, while women do not 
have any prominent place and are even presented as co-responsible for the violence that children are exposed to (Nixon och Tutty, 2009).

On the other hand, such terms represent implicit understandings of violence against women. For instance, family violence and domestic violence indicate in which context the violence is located. These representations place the causes of violence on family members and people's homes (Pratt, 2000), with the consequence that the violence might be interpreted as less serious because these terms are associate with people's homes and with privacy (Bacchi, 1999; Hearn \& McKie, 2008). Emphasising the importance of the home also jeopardises focusing on violence among couples who do not live together or violence that occurs outside the home (Hearn \& McKie, 2008; Watson, 2001). Family perspectives also often assume that the violence is caused by dysfunctional individuals or relationships and that such violence should be addressed on an individual level (Nixon \& Tutty, 2009).

Because family violence and domestic violence are gender neutral, they do not indicate who is considered the offender and who is considered the victim. In other words, gender-neutral terms hide the fact that it is primarily women who are exposed to violence and that the perpetrators most often are men (Holmberg, Stjernqvist \& Sörensen, 2005). Terms like wife abuse and violence against women, clarify that it is (mostly) women who are subjected to violence, but these terms still conceal the perpetrator. A term that highlights the more complex nature of violence, and reveals both perpetrator and victim, is men's violence against women. Although gender-neutral terms hide the gender of both perpetrators and victims, some argues even though gender-neutral terms are used in policies, these policies still interpret and explain violence from a gender perspective (Murray \& Powell, 2009; Hearn \& McKie, 2008). For example, some countries in Central and Eastern European include implicit gender-equality elements in their gender-neutral perspectives (Krizan \& Popa, 2014).

In some contexts, violence against women is described in terms of honour-related violence, a term specifically focusing on immigrant populations (Burman, 2012; Carbin, 2014; Hong, 2014). Some argue that honour-related violence is to be seen as a form of gender-based violence, while others are critical of such an approach because such violence can also affect men (Gill, 2010; Idriss, 2017). In a Finnish context, Hong (2014) found two forms of causal explanations for such violence. The first was 
related to a lack of gender equality, while the other was related to a culture in which the violence was framed as a consequence of power relations in patriarchal families, men's backgrounds, and social roots in women's countries of origin and in immigrant communities. The term honour-related violence might affect how to interpret the violence because honour can have many meanings, and it is often associated with respect and dignity and can thus lead to the appearance of such violence as defendable (Gill \& Brah, 2014).

In addition, policies can refer to various forms of violence such as sexual and physical violence; psychological, social, and emotional violence; social isolation; economic violence; and damage of property (Murray \& Powell, 2009). Concepts such as abuse, violence, and battery indicate physical violence, while concepts such violation and insult might be more difficult to define (Hearn \& McKie, 2008). Definitions of violence and violent acts are thus central, not only because they determine how violence is explained and understood and should be treated, also because they affect how we use statistics to understand the problem (Itzin, 2000).

\section{Swedish policy context}

In years past, there was great tolerance for men's violence against women in Sweden. The violence was looked upon as a private issue outside the public policy domain, and violence against women was explained by alcohol consumption among men, marital or family relationship problems, and other individual problems, but such violence began to be interpreted as a problem due to gender aspects when the Violence Against Women Act was adopted in 1998 (Leander, 2006; Nilsson, 2009; Wendt, 2002). Today Sweden is one of the few countries in Europe that considers violence against women from a structural gender-equality perspective, and the responsibility for helping and supporting women subjected to violence is stated in the Swedish Social Services Act (SFS 2001:453. Socialtjänstlagen ([Cit. SoL].). A structural gender-equality perspective emphasises women as particularly vulnerable, and it understands violence as a universal problem, meaning that it can affect individuals regardless of class, age, functional ability, ethnicity, or personal beliefs (Krizan \& Popa, 2014). Hearn, Strid, Husu, and Verloo (2016) state that Swedish policies visualise the interaction between gender and other 
inequality aspects (age, ethnicity, disability, etc.) through the division of women into different target groups, the categorisation of women in "particularly vulnerable groups" is, according to them, a way to emphasise that violence is interpreted from an intersectional perspective (i.e. it takes into account gender and various aspects that can complicate the situation of women). However, critics argue that Swedish legislation is exclusionary in both how it frames the problem of violence and how it is applied. Ekström (2012) is of the opinion that the categorisation and the attention to different specific aspects of inequality place the responsibility for the violence on women and not on social structures in society, which might result in inadequate support that does not meet women's individual needs (Ekström, 2012). Some also claim that Swedish policies do not problematise violence against women theoretically to any significant extent and that violence is framed as problem of individuals in heterosexual relationships (Burman, 2010; 2012; Wendt, 2012). Others point out that foreign-born women's vulnerability in practice is considered a non-Swedish problem because women who lack a permanent residence permit do not have the same legal rights as Swedish-born women. In addition, women subjected to so-called honour-related violence are interpreted and framed as either active agents (if they have left their family) or as victims due to cultural aspects (Burman, 2012; Carbin, 2014). Honour-related violence is also, according to some, represented as a matter of integration or lack of integration in Swedish society (Balkmar, Iovanni \& Pringle, 2009).

\section{Methodology}

To analyse discourses of men's violence against women in Swedish policies, the study used Carol Bacchi's (1999) social constructivist approach What's the Problem Represented to Be? (WPR). In line with Bacchi, we regard discourse as more than language. Discourses are also ideas, beliefs, and theories about the world that are used to frame a problem, and a basic assumption in WPR is that policies contain both explicit and implicit framings of a problem, i.e. problem representations. There might, in other words, be different underlying understandings of causes of violence against women within a text that are in contrast to those understandings that are clearly stated in the policy. WPR makes it possible to study how the 


\section{Helena Hoppstadius - Men's Violence Against Women}

discourse and the use of language around a representation of a problem affect how the problem is perceived, the possible assumptions that underlie the problem, and how the effects differ when some issues are considered problematic while others are considered problem-free. Policies based on this approach are not only considered as attempts to solve a particular problem, but also as things that can actually create or constitute a problem. The framing of a problem is therefore central because it will consequently affect what we consider needs to be done to address the problem. It is therefore important to study concepts such as domestic violence and family violence to see how they are part of the problem representation in a policy (Bacchi, 1999). Bacchi's approach is based on the following critical questions with respect to the main question of what it is represented as a "problem" in a specific policy (Question 1). What deep-seated presuppositions or assumptions underlie this representation of the "problem" (problem representation)? (Question 2) How has this representation of the "problem" come about? (Question 3) What is left unproblematic in this problem representation? Where are the silences? Can the 'problem' be thought about differently? (Question 4) What effects (discursive, subjectification, lived) are produced by this representation of the 'problem'? (Question 5) How and where has this representation of the "problem" been produced, disseminated and defended? How has it been and/or how can it be disrupted and replaced? (Question 6) (Bacchi \& Goodwin, 2016, p. 20).

The problem in focus in this study is men's violence against women, and the material examined consists of five Swedish public working guidelines derived from the Swedish Action Plan (Skr. 2007/08:39) concerning violence against women. The focus of the individual guides is women with addiction or addiction problems, women with disabilities, elderly women, women with a foreign background, and persons exposed to honour-related violence and oppression. The overall purpose that unites these guides is to improve awareness and competence in matters of violence among professions operating within areas such as the social services, health care, the police, and NGOs. In addition to providing information and knowledge about women subjected to violence in general, the guides focus on the specific situations of the previously mentioned groups of women, children subjected to violence, society's responsibilities, different interventions, and guidance on how to meet and act when supporting women subjected to 
violence. The guides were published in 2011 and 2013 and can be accessed via the National Board of Health and Welfare ${ }^{1}$. Table 1 lists the included guidelines.

Table 1

Included working guidelines.

Year of Publication, Title

1 Socialstyrelsen (2011a). Sällan sedda: utbildningsmaterial om våld mot kvinnor med funktionsnedsättning [Looking the Other Way: A Study Guide to Female Victims of Violence with Disabilities]. Stockholm: Socialstyrelsen

2 Socialstyrelsen (2011b). Skylla sig själv?: utbildningsmaterial om våld mot kvinnor med missbruks- eller beroendeproblem [Their Own Fault? A Study Guide to Female Victims of Violence with Substance Abuse or Addiction Problems]. Stockholm: Socialstyrelsen.

3 Socialstyrelsen (2013a). Blånader och silverhår: utbildningsmaterial om våld mot äldre kvinnor [Bruises and Silver Hair: A Study Guide to Violence Against Older Women]. Stockholm: Socialstyrelsen.

4 Socialstyrelsen (2013b). Ensam och utsatt: utbildningsmaterial om våld mot kvinnor med utländsk bakgrund [Alone and Vulnerable: A Study Guide to Violence Against Women With a Foreign Background]. Stockholm: Socialstyrelsen.

$5 \quad$ Socialstyrelsen (2013c). Vänd dem inte ryggen: utbildningsmaterial om hedersrelaterat våld och förtryck [Don`t Turn Them Away: A Study Guide to Honour Related Violence and Oppression]. Stockholm: Socialstyrelsen.

Initially, the linguistic characteristics of the texts were analysed through a textual reading of the parts describing violence against women and social services responsible for supporting these women, in order to get an overview of the discursive processes in the working guidelines. Then three different aspects of the texts were studied. The first aspect aimed to identify how 


\section{Helena Hoppstadius - Men's Violence Against Women}

violence against women is termed, it was an analysis of the words used to describe men's violence against women. The second aspect investigated framings of violence. Words, statements and assumptions, as well as interventions claiming to address the problem, were explored to determine which theories the guides use to explain violence against women, including both explicit and implicit framings. In other words, the analysis to determine if the violence is interpreted from a structural gender-equality perspective or as the result of other causes. The last aspect investigated how violence against women is defined. The reading focused on words and statements describing violence against women in order to determine which acts are considered to be violent acts.

In order to provide an alternative picture of how the discourses in the working guidelines can be understood, I theorised on what these representations hide, the possible consequences of this ignorance, and who most likely will benefit from these representations. The results are presented under the following headings: Terms used to name violence against women, Framings of violence against women, and Definitions of violence. Since language use affects the meaning of sentences in a text, the included quotations have been translated to illustrate their meaning.

\section{Results}

\section{Terms used to name violence against women}

How violence against women is termed is vital because it says something about who are included (or excluded) as victims of violence and as perpetrators. The analysis shows that the guides use two disparate genderneutral terms hiding both the victims and perpetrators, as well as their genders - violence in close relationships (VCR) and honour-related violence and oppression (HRV). VCR points out in what kind of relationship the violence is perpetrated, while HRV indicates the underlying causes of the violence.

It is primarily the partners or former partners of the women, other family members, and relatives who are considered to be closely related persons (namely, the perpetrator) in VCR. It can also be other persons with different kinds of relationships to women, for example professionals within special 
accommodation, personnel within health and social care, neighbours, as well as persons who have otherwise had a close relationship with the victim. For women with alcohol abuse or addiction problems, closely related persons also include temporary personal contacts, police officers, prison guards, and treatment specialists (Socialstyrelsen, 2011b, p. 16). The term VCR does not say anything about who primarily are considered to be victims of violence, but according to the guidelines both women and men can be subjected to violence.

The term "close relation" can thus indicate that there is a closeness between victims and perpetrators, or that the perpetrator is spatially close. These representations show that it is a woman's own individual life situation that determines who is close to her or not, with the consequence that it is sometimes difficult to determine who is to be considered a closely related person (i.e. perpetrator) or not.

When it comes to HRV, the term indicates why women are subjected to violence, namely that the violence occurs in a family with norms of honour. Because the word "honour" is often associated with respect and dignity, such violence might be understood as legitimate and understandable (cf. Gill \& Brah, 2014). Although the term hides both victims and perpetrators, but the guide mentions victims of HRV as women, men, and transgender persons. Those who are stated as possible perpetrators is a more limited group of peoples than those in VCR, and it includes only men and women within in the immediate family and other close relatives. A possible consequence of framing such violence as "family violence" is that violence against foreignborn women outside this inner circle is overlooked and that other kinds of violence (i.e. VCR) are ignored. The description of such violence as occurring within the family also risks that efforts will be aimed only at families and family members and that structural causes of violence in society will be overlooked.

Both VCR and HRV have a clear emphasis on family members and relatives as well as other closely related persons as perpetrators, which locates the violence within the private sphere. This might lead to understandings of the violence as a private problem and thus that violence as a global social problem is ignored. The use of two different terms, including different victims and perpetrators, also creates a distinction between Swedish women and foreign-born women. When violence is associated with women's 


\section{Helena Hoppstadius - Men's Violence Against Women}

backgrounds, there is a risk that the violence will be collectivised and that the solution to the problem and to women's vulnerability will be linked to culture and ethnicity (cf. Gill \& Brah, 2014).

\section{Framings of violence against women}

It is not just the way violence against women is termed that matters. Also central is the framing of the problem, meaning the theoretical understanding of violence against women. Although the guides mention a variety of theories as useful to understanding violence against women, the guides provide only limited information on structural, socioeconomic, sociopsychological, psychological, intersectional, and ecological or holistic perspectives on such violence (Socialstyrelsen, 2013b, p. 13). In addition, there is a cultural, gender, and intersectional perspective in the guide on HRV (Socialstyrelsen, 2013c, p.13). It is not stated which of these perspectives the National Board advocates, if any of them comply with Swedish legislation, or how to use them in social work practice.

However, through the implicit representations of the problem, the guides mainly frame violence against women from a gender perspective. Women are framed in a heteronormative context, which is in line with the equality discourse and the rhetoric surrounding Swedish law. However, the gender of the perpetrator is hidden, and men's part in the violence is diffuse in most of the guides. Only one guide (focusing on violence against women with foreign backgrounds) frames men explicitly as perpetrators. One consequence of this is that men's responsibility for violence is invisible, and specifically the responsibility of Swedish men. In addition, the guides point out that men can be victims of violence, as shown by the following quotation from the guide on violence against elderly women:

Both elderly men and women are subjected to violence - in close relationships, by health and social care workers, by neighbours in special housing, and by participants in day-care. But women are not only exposed to violence because they are older, but specifically because they are women (Socialstyrelsen, 2013a, p. 7).

The quotation highlights that both men and women can be subjected to violence, but it hides the perpetrator. The representation thus moves the 
focus to the woman. The reason why women are subjected to violence is because "they are women", and not because men abuse women, and this is a framing that can lead to an understanding of violence against women as a normal act. The analysis further shows that other causes of why women are subjected to violence are not problematised, as shown by following statement from the guide about women with disabilities:

She is financially dependent on her partner, she would have trouble finding a place of her own, her religious or culture values say that families must be kept intact, and she thinks that keeping the family together is best for the children (Socialstyrelsen, 2011a, p. 43).

These framings neither describe nor problematise these social inequality aspects. The text omits that women generally have lower incomes than men, that it might be the man who controls her economy, and that a solution to the problem of violence might be that the man should move out of the home. The causes of violence can instead be interpreted as individual shortcomings of the woman, which she needs to address in order to limit the violence or to make it to end (see Paterson, 2009). Other statements indicate that a woman's individual characteristics might have an impact on the violence, as seen in a citation from the guide on HRV:

The woman might be afraid of loneliness and isolation, and she lacks support from the outside world (Socialstyrelsen, 2013c, p. 30).

This quotation suggests inherent weaknesses in the woman, and she has to change her way of living to prevent the violence. In other words, she has to learn to live on her own and has to grow a new network outside of her family and cultural context for support. These framings not only move the attention to women from men, they also frame the woman as co-responsible for the violence. These framings also focus on the consequences of violence instead of the causes of violence, which privileges men and disadvantages and subordinates women. Women's own responsibility for limiting and preventing violence becomes particularly evident in the (few) short-term and long-term interventions presented in the guides. These efforts aim to provide women with counselling and support, security planning, sheltered or other temporary housing, and financial assistance. In the long run, the social 


\section{Helena Hoppstadius - Men's Violence Against Women}

services are expected to determine her thoughts about the future, her prospects for employment or other means of support, how her short and long-term housing is to be arranged, and if her personal data need to be protected (Socialstyrelsen, 2011a, p. 73). Even outreach activities and information (Socialstyrelsen, 2011b, p. 80) and municipal action plans (Socialstyrelsen, 2013b, p. 45) aim to reach and pay attention to women in different ways. This implicit individual perspective is strengthened by the lack of information about actions directed against men's violence, such as preventive work. Only one guide (the guide on HRV) indicates a form of prevention through the intervention "work towards change within the family", which leads to an understanding that women are co-responsible for the violent situations and that they have to participate in activities including the perpetrator. Because these representations focus on interventions aimed at women, when addressing the consequences of violence the problem of men's violence can be considered as an individual problem for women. Such representations thus clearly neglect a structural equality perspective.

\section{Definitions of violence}

In addition to how violence is termed and framed, the definitions of violence say something about how violence against women should be understood, and they clarify which actions are to be regarded as violence within a certain context. The guidelines point out that violence against women consists of different patterns of violence and that it often includes several actions of violence. These acts are linked to the terms used to name violence and to the framings of violence; in other words, what is considered as an act of violence depends on whether it refers to VCR or HRV.

According to the guidelines, the following acts are to be regarded as violence in VCR: physical, psychological, and sexual violence; emotional abuse; financial control and material violence; neglect; and violence related to disability (e.g. Socialstyrelsen, 2013a, p. 25). Violence or other abuse is thereby defined as including acts that both are and are not regarded as crimes. The meanings of these forms of violence are described briefly in the guides, but without any further problematisation, and this can make it difficult to determine when, for example, neglect becomes an act of 
violence. Another risk is that not punishable acts might be regarded as less serious.

Acts defined as acts of violence in HRV are not as well-defined as those in VCR, which the guide on HRV points out. The guide states that there is a lack of consensus on actions covered by the definition, but named acts of violence include physical, psychological, and social violence. The violence can be expressed through control and limitation of women's everyday lives, such as choice of clothing, social interactions/activities, education, work, marriage, and divorce. It might also include threats of violence, murderous violence, genital mutilation, and forced marriages (Socialstyrelsen, 2013c, p. 19). It is also emphasized that HRV is different from VCR due to factors not found in VCR, for example, that the woman might have been exposed to violence from an early age and that the violence might be collectively sanctioned (see Socialstyrelsen, 2013c, p. 11).

The division into two distinct forms of violence thus supports the perception that the woman's background (whether she is Swedish or foreign and her relation to the perpetrator) are factors that determine what acts are to be regarded as acts of violence. This means that acts considered as violence are clearly confined to a specific group of women and their ethnicity. Consequently, it becomes difficult to determine in which context acts are presumably turned into violence. For example, the encouragement of a teenager to go home immediately after school can in one context (VCR) be interpreted as the proper upbringing of a child and as kindness, while in another context (HRV) it can be seen as a restriction on freedom of movement and thus defined as an act of violence. Another consequence is that all kinds of violence (VCR) against women with a foreign background risk being interpreted as HRV and that the framing of HRV as more serious than VCR might have the effect that VCR is not considered as much of a risk and therefore is not given sufficient attention.

\section{Conclusion and discussion}

The purpose of this study was to investigate how men's violence against women is represented in five Swedish working guidelines published by the National Board. The study examined how violence against women is termed, framed, and defined and then theorised on what these representations ignore, 
the possible consequences of this ignorance, and who most likely will benefit from these representations.

The study showed that despite the Swedish Government's opinion, namely that violence and abuse of women is the most acute and greatest obstacle to an equal society, these public working guidelines use two genderneutral terms, violence in close relationship (VCR) and honour-related violence and oppression (HRV). These terms consequently conceal that victims of domestic violence most often are women and that the perpetrators most often are men. The violence can thus be perceived as a problem affecting women and men in a similar manner and to an equal extent. These gender-neutral terms mainly include perpetrators in women's private sphere, which means that violence can be interpreted as a kind of family violence. The consequences of this are that violence against women as a major global social problem might be neglected and that efforts might focus on the needs of individuals or families and not on efforts to combat men's violence against women.

When it comes to causes of violence, meaning how the guides frame violence, this study shows that the guides rarely problematise or visualise violence against women from a structural gender-equality perspective. The guides instead frame violence against women as an individual problem in a heterosexual relationship and focus on the consequences of violence. The underlying message is that women need to address different individual problems in order to reduce the violence or to make it end, which in part leads to representations of women as co-responsible for the violence (cf. Hearn \& McKie, 2010; Paterson, 2009). By failing to problematise men's behaviour, gender inequality, structural causes, and effective efforts, the violence is likely continue, which is mostly to the detriment of women.

How violence is defined determines which acts are regarded as act of violence, and such definitions depend on whether the guides refer to VCR or HRV. The division into two different forms of violence supports the perception that a woman's individual background determines which acts are to be regarded as violence (cf. Volpp) and that it matters what a woman's relation to the perpetrator is and whether the woman is Swedish born or foreign born. In other words, the violence is interpreted differently depending on "who she is". A consequence of this categorisation is that HRV is collectivised and that solutions to the problem risk being connected 
to culture and ethnicity and that efforts might focus on integration instead of on the violence itself (cf. Gill \& Brah, 2014; Balkmar et.al., 2009). There are also other risks; for example, when particular attention is on gender equality there is a risk that other inequality aspects affecting a woman's situation are overlooked (Arousell, Carlbom, Johnsdotter, Larsson \& Essén, 2017) and there is the risk that the term used to name HRV can lead to understandings of the violence as understandable and defensible (cf. Gill \& Brah, 2014). As a result of the dichotomous groupings, the guidelines tend to treat HRV in sharp contrast to, and sometimes as more seriously than "our violence" it will say VCR, which might be interpreted as a form of "mainstream violence". The effect is that individuals from Swedish society are interpreted as good and equal, in contrast to individuals with backgrounds in foreign countries.

When summarising the results, three primary findings come to the fore. The first is that these guides frame violence against women within close relations and within families in a heterosexual context, and the violence is also framed as an individual problem of women. The second is that the guides promote a division between violence against Swedish-born women and foreign-born women. This is done despite the fact that the term VCR includes all women, even foreigners. Third, equality in the guides seems to be more about the inclusion of men than about looking after women's situations. The representations in the guides frame women as weak and in a subordinated position, which is indicated by the titles of the guides that portray women without power and agency - "Alone and Vulnerable", "Bruises and Silver Hair", "Don't Turn Them Away", "Looking the Other Way", and "And Their Own Fault?" (Socialstyrelsen, 2011a; Socialstyrelsen, 2011b, Socialstyrelsen, 2013a; Socialstyrelsen, 2013b \& Socialstyrelsen, 2013c). The attention on women's abilities as well as their individual situation due to different inequality aspects visualised by the guides will consequently affect social work practice because the categorisation within the guides at least to some extent reflects target groups of needy people within the Social Services Acts.

How we interpret and understand violence against women might affect how violence can be predicted, prevented, and treated (Cunningham, Jaffe, Baker, Dick, Malla, Mazaher \& Poisson, 1998), and women subjected to violence can therefore be affected by these representations depending on 


\section{Helena Hoppstadius - Men's Violence Against Women}

how social workers interpret and apply these guides. If violence against women is attributed to individual causes, and if different aspects are considered one at a time, there is a risk that women's overall situation and structural causes for violence will be overlooked. This might lead to inadequate support measures at the community level, as well as a lack of measures with a global perspective, which will have negative consequences for women worldwide. There is therefore a risk that these representations maintain gender hierarchies and other structural and societal inequalities and ignore violence against women as a major global social problem.

Understanding violence through this analysis hardly presents the only truth. The study has tried to sort out the specific characteristics of each part studied in the text, but texts can of course imply other representations. Additionally, the approach did not intend to evaluate policies or to clarify what the "real" problem is in order to develop appropriate solutions. The analysis should instead be considered as an attempt to question representations of the problem of men's violence against women and to give an example of how discourses within the guides can be interpreted and understood. Thus this work might be valuable for social workers and social work students, as well as for others working with women subjected to violence, in order to encourage a critical view of the knowledge contained within various working guidelines and documents.

The study is limited by focusing on only five documents published by the National Board. In order to obtain a more comprehensive picture of how men's violence against women is represented in a Swedish context, the analysis should be complemented with additional policies as well as other public documents published by different authorities.

Lastly, the work with this analysis involved a focus on women's situations, but this do not mean that men cannot be subjected to violence or that women cannot be violent. Women are at focus simply because vastly more women are subjected to violence compared to men globally and because society's patriarchal structures affect women more negatively than men in similar situations. The analysis is therefore influenced by the researchers' view of the problem, and it is also influenced by the context in which the researchers are located, as social science researcher with interest and knowledge in critical social work. 
This study has provided an understanding of how discourses of violence against women in policies can be interpreted, and it raises questions for further studies. An area of interest is how social workers interpret and understand violence, and because discourses refer to knowledge rather than to language it is also important to examine what knowledge social workers have and how they apply their knowledge in social work practice. Interesting for further studies would also be to examine which discourses social workers take part of in their work in supporting women subjected to violence.

\section{Notes}

${ }^{1} \mathrm{http}: / / \mathrm{www}$. socialstyrelsen.se

\section{References}

Arousell, J., Carlbom, A., Johnsdotter, S., Larsson, E., \& Essén, B. (2017). Unintended Consequences of Gender Equality Promotion in Swedish Multiculural Contraceptive Counseling: A Discourse Analysis. Qualitative Health Research, 27(19), 1518-1528.

Bacchi, C \& Goodwin, S. (2016). Poststructural Policy Analysis [electronic resource].

Bacchi, C. (1999). Women, Policy and Politics: The Construction of Policy Problems. London: SAGE Publications.

Balkmar, D., Iovanni, L., \& Pringle, K. (2009). A Reconsideration of Two "Welfare Paradises". Men and Masculinities, 12(2), 155-174.

Burman, M. (2010). The Ability of Criminal Law to Produce Gender Equality: Judicial Discourses in the Swedish Criminal Legal System. Violence Against Women, 16(2), 173-188.

Burman, M. (2012). Immigrant Women Facing Male Partner Violence Gender, Race and Power in Swedish Alien and Criminal Law. feminists@law, 2(1), 1-26.

Burnett, C., Ford-Gilboe, M., Berman, H., Wathen, N., \& Ward-Griffin, C. (2016). The Day-to-Day Reality of Delivering Shelter Services to Women Exposed to Intimate Partner Violence in the Context of System and Policy Demands. Journal of Social Service Research, 117. doi:10.1080/01488376.2016.1153562 
Carbin, M. (2014). The requirement to speak: Victim stories in Swedish policies against honour-related violence. Women's Studies International Forum, 46(Sep-Oct), 107-114.

Cunningham, A., Jaffe, P. G., Baker, L., Dick, T., Malla, S., Mazaheri, N., \& Poisson, S. (1998). Theory-derived explanations of male violence against female partners: Literature update and related implications for treatment and evaluation (pp. 1-10). London, UK: London Family Court Clinic.

Eduards, M. (2002). Förbjuden handling. Om kvinnors organisering och feministisk teori [Prohibited action. Women's organization and feminist theory]. Malmö: Liber ekonomi.

Ekström, V. (2012). Inte bara kvinna Våldsutsatta kvinnor och deras behov av stöd - konstruktioner och komplikationer i svenskt offentligt tryck [Not just a women - Abused women and their need for support constructs and complications in Swedish public publications]. Nordic Journal of Law and Justice, 3(138), 51-68.

Garcia-Moreno, C., Jansen, H., Ellsberg, M., Heise, L. \& Watts, CH. (2006). Prevalence of intimate partner violence: findings from the WHO multi-country study on women's health and domestic violence, i Lancet. Vol: 368 s. $1260-69$

Gill, A. (2010). Reconfiguring honour-based violence as a form of gendered violence. In M. Idriss \& T. Abbas (Eds.), Honour, violence, women and Islam (pp. 218-231). London: Routledge-Cavendish.

Gill, A. K, \& Brah, A. (2014). Interrogating cultural narratives about 'honour'- based violence. European Journal of Women's Studies, 21(1), 72-86. DOI: $10.1177 / 1350506813510424$.

Hearn, J, Strid, S., Husu, L., \& Verloo, M. (2016). Interrogating violence against women and state violence policy: Gendered intersectionalities and the quality of policy in The Netherlands, Sweden and the UK. Current Sociology, 64(4), 551-567.

Hearn, J., \& McKie, L. (2008). Gendered policy and policy on gender: The case of 'domestic violence'. Policy And Politics (Print), 36(1), 75-91.

Hearn, J., \& McKie, L. (2010). Gendered and Social Hierarchies in Problem Representation and Policy Processes: 'Domestic Violence' in Finland and Scotland. Violence Against Women, 16(2), 136-158. DOI: $10.1177 / 1077801209355185$ 
Heise L., \& Garcia-Moreno C. (2002). Violence by intimate partners. In: E. G. Krug, L. L. Dahlberg, J. A. Mercy, B. Z. Zwi and R. Lozano (eds). World report on violence and health (87-121). Geneva, World Health Organization.

Holmberg, C., Stjernqvist, U. \& Sörensen, E. (2005). Våldsamt lika och olika: om våld $i$ samkönade parrelationer [Violently alike and unalike: on violence in same-sex relationships]. Stockholm: Stockholms universitet, Centrum för Genusstudier.

Hong, T. (2014). Discourses on Honour-Related Violence in Finnish Policy Documents. NORA - Nordic Journal of Feminist and Gender Research, 1-16. DOI: 10.1080/08038740.2014.964648

Hvitfeldt, T., Westerberg, S. \& Irlander Strid, A. (2016). Nationella trygghetsundersökningen 2015 [The Swedish Crime Survey 2015]. Brå, Brottsförebyggande rådet.

Idriss, M. (2017). Not domestic violence or cultural tradition: Is honourbased violence distinct from domestic violence? Journal of Social Welfare and Family Law, 39(1), 3-21.

Itzin, C. (2000). Gendering domestic violence: The influence of feminism on policy and practice. I J. Hanmer \& C. Itzin (Eds.), Home truths about domestic violence: Feminist influences on policy and practice (pp. 356-380). London: Routledge.

Johnsson-Latham, G. (2005). Patriarkalt våld som hot mot mänsklig säkerhet: en kartläggning av åtgärder mot patriarkalt våld och förtryck, särskilt $i$ hederns namn, mot kvinnor och homo- och bisexuella samt transpersoner [Patriarchal violence as a threat to human security: a report of measures against patriarchal violence and oppression, especially in the name of the honour, violence against women and gay and bisexual and transgender]. Stockholm: Regeringskansliet.

https://www.regeringen.se/49bb89/contentassets/d8d7512f54bd4ac1b 15a4d6287d72374/patriarkalt-vald-som-hot-mot-mansklig-sakerhet

Krizsan, A., \& Popa, R. (2010). Europeanization in Making Policies against Domestic Violence in Central and Eastern Europe. Social Politics, 17(3), 379-406. doi:http://dx.doi.org/10.1093/sp/jxq010 
Krizsan, A., \& Popa, R. (2014). Frames in contestation: Gendering domestic violence policies in five central and Eastern European countries. Violence Against Women, 20(7), 758-782.

Leander, K. (2006). Reflections on Sweden's Measures against Men's Violence against Women. Social Policy and Society, 5(1), 115-125.

Doi: $10.1017 /$ S1474746405002794

Ljungwald, C. (2011). The emergence of the crime victim in the Swedish Social Services Act. Diss. Stockholm: Stockholms universitet, 2011. Stockholm.

Lorentzen, M. (2008). Multikulturella visioner: hedersrelaterat våld och socialt arbete $i$ medierna [Multicultural visions: honour related violence and social work in media]. Lic. Växjö : Växjö universitet, 2008. Växjö.

Mattsson, T. (2013). Motstånd och neutralisering. Kön, makt och professionalitet i arbetet med våld i nära relationer [Resistance and neutralization Gender, power and professionalism in working with intimate partner violence]. Socialvetenskaplig tidskrift, 20,3-4, 150167.

Murray, S., \& Powell, A. (2009). 'What's the Problem?': Australian Public Policy Constructions of Domestic and Family Violence. Violence Against Women. Doi: 10.1177/1077801209331408

Nilsson, G. (2009). Könsmakt eller häxjakt?: antagonistiska föreställningar om mäns våld mot kvinnor [Gender power or witch-hunt?: antagonistic beliefs about men's violence against women]. Diss. Lund : Lunds universitet, 2009. Lund.

Nixon, K. L., \& Tutty, L. M. (2009). 'Where Have All the Women Gone?' Woman Abuse and Canadian Social Policy. Canadian Review of Social Policy/Revue Canadienne de Politique Sociale(63-64), 63-82.

Paterson, S. (2009). (Re)Constructing women's resistance to woman abuse: Resources, strategy choice and implications of and for public policy in Canada. Critical Social Policy, 29(1), 121-145.

Pratt, C. (2000). Violence against women: A cross-national study of policy in Barbados and New York. Caribbean Journal of Criminology and Social Psychology, 5(1/2), 1-39.

Regeringen (2018) Mäns våld mot kvinnor ska upphöra - Regeringens insatser [Men's violence against women must stop - The Government 
efforts]. https://www.regeringen.se/artiklar/2017/12/regeringenssamlade-atgarder-mot-sexuellt-vald-och-trakasserier/

SFS 2001:453. Socialtjänstlagen [Cit. SoL]. [Social Services Act]. Stockholm:

Socialdepartementet.

http://www.riksdagen.se/sv/Dokument-

Lagar/Lagar/Svenskforfattningssamling/Socialtjanstlag-2001453_sfs2001-453/

Skr (2007/08:39). Handlingsplan för att bekämpa mäns våld mot kvinnor, hedersrelaterat våld och förtryck samt våld $i$ samkönade relationer [Action Plan for Combating Men's Violence against Women, Violence and Oppression in the Name of Honour and Violence in Same-sex Relationships].Stockholm: Riksdagen. http://www.regeringen.se/rattsdokument/skrivelse/2007/11/skr.20070839/

Skr (2016/17:10). Makt, mål och myndighet - feministisk politik för en jämställd framtid [Power, goals and agency - a feminist policy]. Stockholm:

Riksdagen.

https://www.regeringen.se/4ace09/globalassets/regeringen/dokument /socialdepartementet/jamstalldhet/makt-mal-och-myndighet---

feministisk-politik-for-ett-jamstallt-samhalle-skr.-2016_17-10.pdf

Socialstyrelsen (2011a). Sällan sedda: utbildningsmaterial om våld mot kvinnor med funktionsnedsättning [Looking the Other Way: A Study Guide to Female Victims of Violence with Disabilities]. Stockholm: Socialstyrelsen.

http://www.socialstyrelsen.se/Lists/Artikelkatalog/Attachments/18415 /2011-9-6.pdf

Socialstyrelsen (2011b). Skylla sig själv?: utbildningsmaterial om våld mot kvinnor med missbruks- eller beroendeproblem [Their Own Fault? A Study Guide to Female Victims of Violence with Substance Abuse or Addiction Problems]. Stockholm: Socialstyrelsen. http://www.socialstyrelsen.se/Lists/Artikelkatalog/Attachments/18433 /2011-10-1.pdf

Socialstyrelsen (2013a). Blånader och silverhår: utbildningsmaterial om våld mot äldre kvinnor [Bruises and Silver Hair: A Study Guide to Violence Against Elderly Women]. Stockholm: Socialstyrelsen. 
http://www.socialstyrelsen.se/Lists/Artikelkatalog/Attachments/19315 12014-1-4.pdf

Socialstyrelsen (2013b). Ensam och utsatt: utbildningsmaterial om våld mot kvinnor med utländsk bakgrund [Alone and Vulnerable: A Study Guide to Violence Against Women With a Foreign Background]. Stockholm:

Socialstyrelsen. http://www.socialstyrelsen.se/Lists/Artikelkatalog/Attachments/19318 12014-1-7.pdf

Socialstyrelsen (2013c). Vänd dem inte ryggen: utbildningsmaterial om hedersrelaterat våld och förtryck [Don't Turn Them Away: A Study Guide to Honour Related Violence and Oppression]. Stockholm: Socialstyrelsen.

http://www.socialstyrelsen.se/Lists/Artikelkatalog/Attachments/19317 /2014-1-6.pdf

Volpp, L. (2005). A Black Feminist Reflection on the Antiviolence Movement. In Sokoloff, N.J. \& Pratt, C. (Eds.). Domestic violence at the margins: readings on race, class, gender, and culture.(s. 50-55). New Brunswick, N.J.: Rutgers University

Watson, G. (2001). A Critical Response to the Keys Young Report: Ending Domestic Violence? Programs for Perpetrators. Australian and New Zealand Journal of Family Therapy, 22(2), 90-95.

Wendt, M. (2002). Rädslans politik: våld och sexualitet $i$ den svenska demokratin [The politics of fear violence and sexuality in Swedish democracy]. Diss. Stockholm: Univ., 2002. Malmö.

Wendt, M. (2012). Recreating Ignorance? The Politisation of Feminist Research into Men's Violence against Women. Australian Feminist Studies, 27(71), 93-109.

World Health Organization (2014). Global status report on violence prevention 2014. Geneva: World Health Organization, 2014 [electronic resource]. 
GÉNEROS -Multidisciplinary Journal of Gender Studies, 7(2)

Helena Hoppstadius Department of Social Work, Mid Sweden University, Sweden

E-mail address: helena.hoppstadius@miun.se 